\title{
Bovine Leukemia Virus High Tax Molecular Clone Experimentally Induces Leukemia/Lymphoma in Sheep
}

\author{
Kosuke OKADA ${ }^{1}$, Norihiro NAKAE'), Konomi KURAMOCHI ${ }^{1}$, Shan-ai YIN ${ }^{1)}$, Manabu IKEDA ${ }^{1}$, Shigeaki TAKAMI ${ }^{1}$, \\ Tou-ichi HIRATA ${ }^{2)}$, Masanobu GORYO ${ }^{1}$, Shigeru NUMAKUNAI ${ }^{1}$, Shin-nosuke TAKESHIMA ${ }^{3}$, \\ Masahiko TAKAHASHI ${ }^{3)}$, Shigeru TAJIMA ${ }^{3)}$, Satoru KONNAI ${ }^{4}$, Misao ONUMA ${ }^{4)}$ and Yoko AIDA ${ }^{3)}$ \\ ${ }^{1)}$ Department of Veterinary Pathology, ${ }^{2)}$ Field Science Center, Faculty of Agriculture, Iwate University, 3-18-8 Ueda, Morioka, Iwate \\ 020-8550, ${ }^{3)}$ Retrovirus Research Unit, RIKEN, 2-1 Hirosawa, Wako, Saitama 351-0198 and ${ }^{4)}$ Graduate School of Veterinary Medicine, \\ Hokkaido University, Sapporo, Hokkaido 060-0818, Japan
}

(Received 6 May 2005/Accepted 30 August 2005)

ABSTRACT. Sheep were inoculated with high tax coded pBLV-IF (H group, Nos.1-5) of bovine leukemia virus (BLV), wild tax coded pBLV-IF (W group, Nos. 6-11), or control plasmid (C group, Nos. 12-14). During the observation period (4 to 46 months), 5 of 5 cases in $\mathrm{H}$ group and 3 of 6 cases (Nos. 6, 7,9) in $\mathrm{W}$ group became positive for gp 51. Only 1 case in $\mathrm{H}$ group became leukemic, and one case each of $\mathrm{H}$ and $\mathrm{W}$ groups developed lymphoma. In No. 3, lesions were found in multiple organs including the lymph nodes, gastrointestinal tract following abomasum, and heart. In No. 6, lesions of lymphoma were found only in the jejunum and heart. Morphologically, small to middle-sized lymphocytic neoplastic (NP) cells were found in both cases, but lymphoblastic NP cells were found only in No. 3. By immunohistochemical examination, the phenotypes of NP cells were determined as $\mathrm{CD}^{-}, \mathrm{CD}^{-}, \mathrm{CD}^{-}-\mathrm{CD}^{-} \alpha^{-}, \mathrm{sIgM}^{+}$, $\lambda$ light chain ${ }^{+}, \mathrm{B}-\mathrm{B} 4^{+}, \mathrm{MHC}$ class $\mathrm{II}^{+}$in both case. The results of this study indicate that inoculation of pBLV-IF can induce lymphocytic and lymphoblastic leukemia/lymphoma in sheep. Additionally, it is suggested that the expression rate of tax gene is not associated with the development of leukemia/lymphoma in sheep experimentally inoculated with pBLV-IF.

KEY WORDS: bovine leukemia virus, lymphoma, molecular clone, sheep, tax.

Tax protein, which is encoded in $\mathrm{pX}$ region of the $\mathrm{BLV}$, affects the host-side gene expression and function associated with cellular proliferation as well as activating viral gene expression and viral replication [16], so it has been thought to be a main cause of the development of BLVinduced leukemia [5]. Tajima and Aida [10] identified a tax mutant, D247G, which has a missense mutation at codon 247 (from Asp to Gly) as compared with $\lambda$ BLV-1 [9], and exhibits markedly stronger transcriptional activity than the wild type $\operatorname{tax}$ (wild $\operatorname{tax}$ ) protein from the infectious molecular clone of BLV [5]. Inabe et al. [5] constructed the wildtype infectious BLV molecular clone (wild tax pBLV-IF) and Tajima et al. [10] constructed the mutant infectious molecular clone of BLV that encoded D247G, with elevated transactivation activity, and also reported that high tax pBLV-IF produced many viral proteins and particles. These produced viral particles infected cultured cells more effectively than these wild tax pBLV-IF transfected. But, in in vivo study, they found no significant difference in the viral load or the expression of viral RNA between sheep inoculated with wild tax and sheep inoculated with high tax [11]. Thus, we inoculated with high tax or wild tax pBLV-IF into sheep followed by long-term observation, and performed hematological, serological, gross observation, histopathological and immunohistochemical studies to determine whether pBLV-IF could induce ovine lymphoma.

\section{MATERIALS AND METHODS}

Animals: 14 sheep, 12 Suffolk and 2 mixed breed that did not have antibody to BLV were purchased from Japan Lamb Company (Hokkaido, Japan) for this experiment. The profile of these sheep is listed in Table 1.

Experimental design: We assigned the animals to be inoculated with high tax pBLV-IF (group H [H1: Nos. 1, 2, H2: Nos. 3-5]), wild tax pBLV-IF (group W [W1: Nos. 6-8, W2: Nos. 9-11]), and control plasmid as negative control (group C [Nos. 12-14]). In groups H1 and W1, $200 \mu \mathrm{g} /$ head of each plasmid enveloped in Dotap liposomal tranfection reagent (Roche Dianostics, Mannhein, Germany) [15] was injected to the dorsal portion of the bilateral shoulders of sheep subcutaneously. In groups H2, W2 and C, $200 \mu \mathrm{g} /$ head of each pBLV-IF or control plasmid enveloped in mixed solution of $N$-( $\alpha$-trimethylammonioacetyl $)$-didodecyl-D-glutanate chloride ( $1 \mu \mathrm{mol})$, dilauroyl phosphatidylcholine (2 $\mu \mathrm{mol})$, and dioleoyl phosphatidylethanolamine (2 $\mu \mathrm{mol})$, was injected to the dorsal portion of the bilateral shoulders of sheep subcutaneously [15]. We set the observation period to 4 years, but if sheep developed lymphoma or died by accident before termination, examination was performed at the time. All experiments were conducted according to the guidelines of The Iwate University.

Hematological and serological examination: Blood was collected from the jugular vein. The heparin-contained blood was used for counting of red blood cells (RBC) and white blood cells (WBC) with an automated cell counter for animals (Celltac MENK-5258, Nihon Koden, Tokyo, Japan), and preparation of blood smear samples stained with May Giemsa for differential white blood count. The serum obtained was used for detection of antibody to BLV glyco- 
Table 1. Clinical, hematological and serological findings of sheep

\begin{tabular}{|c|c|c|c|c|c|c|c|c|c|c|c|c|}
\hline \multirow{4}{*}{$\begin{array}{c}\text { Group } \\
\text { H1 }\end{array}$} & \multirow{4}{*}{$\begin{array}{c}\begin{array}{c}\text { Case } \\
\text { No. }\end{array} \\
1 \\
2\end{array}$} & \multirow{3}{*}{$\begin{array}{c}\text { Sheep } \\
0.1\end{array}$} & \multirow{3}{*}{$\frac{\text { Breed }^{\text {a) }}}{\mathrm{Cr}}$} & \multirow{4}{*}{$\begin{array}{c}\text { Sex } \\
\text { 우 } \\
\text { castrated }{ }^{7}\end{array}$} & \multicolumn{2}{|c|}{ Inoculation } & \multirow{2}{*}{\multicolumn{2}{|c|}{$\begin{array}{l}\text { ID }(g p, p)^{c)} \\
\text { gp sero- } \\
\text { conversion } \\
\text { day }\end{array}$}} & \multicolumn{3}{|c|}{ Hematological findings $(/ \mu l)^{\mathrm{d})}$} & \multirow[b]{2}{*}{$\begin{array}{l}\text { Lesion of } \\
\text { lymphoma }\end{array}$} \\
\hline & & & & & \multirow{3}{*}{$\begin{array}{l}\text { Material }^{\text {b) }} \\
\text { high tax } \\
\text { high tax }\end{array}$} & \multirow{3}{*}{$\begin{array}{c}\begin{array}{c}\text { Age } \\
\text { (years) }\end{array} \\
2 \\
1.2\end{array}$} & & & \multirow{3}{*}{$\begin{array}{c}\operatorname{Lym}(/ \mu l) \\
2,346 \\
6,320 \\
\end{array}$} & \multirow{3}{*}{$\begin{array}{r}\mathrm{MNC}(/ \mu l) \\
2,381 \\
6,320\end{array}$} & \multirow{3}{*}{$\begin{array}{c}\text { AtMC }(/ \mu l) \\
0 \\
0\end{array}$} & \\
\hline & & & & & & & $(+,-)$ & 41 & & & & - \\
\hline & & 287 & $\mathrm{Su}$ & & & & $(+,-)$ & 55 & & & & - \\
\hline \multirow[t]{3}{*}{$\mathrm{H} 2$} & 3 & 234 & $\mathrm{Su}$ & ত & high tax & 1 & $(+,-)$ & 41 & 6,090 & 201,276 & 194,880 & + \\
\hline & 4 & 195 & $\mathrm{Su}$ & 우 & high $\operatorname{tax}$ & 1 & $(+,-)$ & 55 & 4,088 & 4,256 & 0 & - \\
\hline & 5 & 240 & $\mathrm{Su}$ & $\sigma^{7}$ & high $\operatorname{tax}$ & 1 & $(+,-)$ & 776 & 6,384 & 6,636 & 84 & - \\
\hline \multirow[t]{3}{*}{ W1 } & 6 & 279 & $\mathrm{Su}$ & castrated $\overbrace{}^{\nearrow}$ & wild $\operatorname{tax}$ & 1.2 & $(+,+)$ & 34 & 7,238 & 7,546 & 154 & + \\
\hline & 7 & $1-4$ & $\mathrm{Cr}$ & 우 & wild $\operatorname{tax}$ & 0.5 & $(+,-)$ & 288 & $\mathrm{NE}$ & $\mathrm{NE}$ & - & - \\
\hline & 8 & 250 & $\mathrm{Su}$ & $0^{7}$ & wild $\operatorname{tax}$ & 1.3 & $(-,-)$ & - & $\mathrm{NE}$ & $\mathrm{NE}$ & - & - \\
\hline \multirow[t]{3}{*}{ W2 } & 9 & 109 & $\mathrm{Su}$ & 우 & wild $\operatorname{tax}$ & 1 & $(+,-)$ & 776 & 7,254 & 7,605 & 117 & - \\
\hline & 10 & 249 & $\mathrm{Su}$ & $\sigma^{x}$ & wild $\operatorname{tax}$ & 1 & $(-,-)$ & - & 6,160 & 6,160 & 0 & - \\
\hline & 11 & 196 & $\mathrm{Su}$ & 우 & wild tax & 1 & $(-,-)$ & - & 3,300 & 3,350 & 50 & - \\
\hline \multirow[t]{3}{*}{$\mathrm{C}$} & 12 & 111 & $\mathrm{Su}$ & $\sigma^{\top}$ & control plasmid & 1 & $(-,-)$ & - & 5,695 & 6,188 & 100 & - \\
\hline & 13 & 267 & $\mathrm{Su}$ & castrated $\sigma^{\nearrow}$ & control plasmid & 1 & $(-,-)$ & - & 5,460 & 5,460 & 0 & - \\
\hline & 14 & 274 & $\mathrm{Su}$ & castrated $\sigma^{\top}$ & control plasmid & 1 & $(-,-)$ & - & 4,556 & 4,556 & 0 & - \\
\hline
\end{tabular}

a) Su: Suffolk, Cr: Mixed breed. b) high tax: high tax pBLV-IF, wild tax: wild tax pBLV-IF.

c) ID: ager-gel immunodiffusion test, gp: BLV glycoprotein 51, p: BLV internal protein 24.

gp seroconversion days: the day that determined seroconversion for gp post inoculation (pi). (No.6 showed seroconversion for $p$ at day 373 pi.) d) WBC: white blood cell, Lym: Lymphocyte, MNC: Mononuclear cell, AtMC: atypical mononuclear cells, NE: Not examined (These data were obtained from the latest samples).

Table 2. Results of immunohistochemical examination on tumor tissue in sheep with lymphoma (Nos. 3 and 6)

\begin{tabular}{|c|c|c|c|c|}
\hline \multicolumn{3}{|c|}{ Monoclonal antibody } & Number of positive cells $\%$ & $($ mean $\pm \mathrm{SD})$ \\
\hline cell lineage & specificity & dilution & Case No. 3 & Case No. 6 \\
\hline TH97A & CD1 & $\times 66$ & $0.1 \pm 0.2$ & $0.1 \pm 0.2$ \\
\hline GC50A1 & CD4 & $\times 66$ & 0 & 0 \\
\hline ST1 & CD5 & $\times 500$ & $6.9 \pm 4.2$ & $7.0 \pm 7.2$ \\
\hline CACT80C & $\mathrm{CD} 8 \alpha$ & $\times 66$ & $1.8 \pm 1.5$ & $4.5 \pm 4.9$ \\
\hline PIg45A & $\operatorname{sIgM}$ & $\times 66$ & $77.2 \pm 29.4$ & $97.5 \pm 2.2$ \\
\hline BIg501E & $\lambda$ light chain & $\times 330$ & $62.9 \pm 22.3$ & $96.7 \pm 2.9$ \\
\hline BAQ155A & B-B4 & $\times 66$ & $15.7 \pm 10.3$ & $95 \pm 3.5$ \\
\hline TH14B & MHC class II & $\times 200$ & $65.7 \pm 15.5$ & $94.4 \pm 3.8$ \\
\hline
\end{tabular}

protein 51 (gp51) and BLV internal protein (p24) by agargel immunodiffusion (ID) test.

Necropsy and histopathological examination: We performed necrospy of the sheep, which were euthanized by bleeding following the experimental design, or died by accident during the study period, for detailed microscopic examination. Tissue samples were collected from liver, spleen, kidney, heart, lung, lymph nodes and other organs, and fixed with $10 \%$ formalin solution. These samples were embedded in paraffin, sliced into thickness of about $4 \mu \mathrm{m}$ by microtome, and stained with hematoxylin and eosin (HE) for histopathological examination.

Immunohistochemical examination: In cases 3 and 6, which had macroscopic lesions of lymphoma, tissue samples were collected from tumor tissue. These samples were embedded in OCT compound (Sakura Finetechnical Co.,
Ltd., Tokyo, Japan) followed by quick freezing with liquid nitrogen, and preserved at $-80^{\circ} \mathrm{C}$. The frozen tissues were sliced to about $4 \mu \mathrm{m}$ by a high-speed cryostat (CM1900, Leica, Germany), and the sections were extended onto slide glasses processed by $3 \%$ saline acetone solution, dried, and fixed with $100 \%$ ethanol for 8 min. Immunohistochemical examination was performed by the Dextran polymer immunocomplex method. The monoclonal antibody (MoAb) (VMRD, Pullman, WA [2]) (Table 2) to ovine lymphocyte differential antigen was used as a primary antibody. After washing with $0.05 \mathrm{M}$ Tris- $\mathrm{HCl}$ buffered saline, the section was reacted with peroxydase-labelled dextran-binded antimouse immunogloblin goat polyclonal antibody (Dako Envision-System, Labelled Polymer, HRP, Dako Corporation, Carpinteria, CA, U.S.A.) for $60 \mathrm{~min}$.

Calculation of lymphocytic subset: The ratios of $\mathrm{MoAb}$ 
Table 3. Clinical and macroscopic total diagnosis of sheep

\begin{tabular}{|c|c|c|c|c|}
\hline Group & No. & Outcome & Clinical and macroscopic total diagnosis & $\begin{array}{c}\text { Observation period } \\
\text { (days) }\end{array}$ \\
\hline \multirow[t]{2}{*}{ H1 } & 1 & Euthanized & Healthy & 290 \\
\hline & 2 & Death & Open laceration to thoracic cavity by horn & 1,152 \\
\hline \multirow{3}{*}{$\mathrm{H} 2$} & 3 & Euthanized & Lymphocytic leukemia and lymphoma & 1,214 \\
\hline & 4 & Euthanized & Sporadic encapsulated abcess in lung & 1,189 \\
\hline & 5 & Euthanized & Multiple abcess in left posterior lobe of lung & 1,095 \\
\hline \multirow[t]{3}{*}{ W1 } & 6 & Death & Lymphoma around jejunum $(11 \times 10 \times 8 \mathrm{~cm})$ & 1,406 \\
\hline & 7 & Euthanized & Organized/encapsulated abcess (size: head of forefinger) in left and right posterior lobe of lung & 1,055 \\
\hline & 8 & Death & Sever anemia and emaciation & 119 \\
\hline \multirow[t]{3}{*}{ W2 } & 9 & Euthanized & Healthy & 1,095 \\
\hline & 10 & Euthanized & $\begin{array}{l}\text { Sporadic encapsulated abcess in subcutaneous tissue of neck, lung } \\
\text { and lymphonodi retropharyngei laterales }\end{array}$ & 731 \\
\hline & 11 & Euthanized & $\begin{array}{l}\text { Chondroid mass at distal end of right third rib }(31 \times 2.51 \times 2 \mathrm{~cm}) \\
\text { and poor development }\end{array}$ & 1,095 \\
\hline \multirow[t]{3}{*}{$\mathrm{C}$} & 12 & Euthanized & Almost normal & 1,189 \\
\hline & 13 & Alive & Healthy & 200 \\
\hline & 14 & Alive & Healthy & 200 \\
\hline
\end{tabular}

positive cells in immunostained specimens of tumor tissue from Nos. 3 and 6 were calculated under a light microscope with a 40 power objective lens (Olympus BH-2, Tokyo). Two hundred cells were counted in 5 randomized fields of each section, and the cells that had specific-color on the cellular membrane were determined to be positive cells. Average and standard deviation of each MoAb positive cell type were calculated (Table 2).

\section{RESULTS}

Serological examination and hematological examination: The observation period ranged from 4 to 46 months. The results of ID test and the hematological findings of the latest blood samples are shown in Table 1.

In all cases of $\mathrm{H} 1$ and $\mathrm{H} 2$ groups, 2 cases of $\mathrm{W} 1$ group and 1 case of W2 group, the serum antibody to BLV glycoprotein 51 changed to positive in the ID test. In only one of all 14 animals (No. 6), the serum antibody to BLV internal protein 24 changed to positive at day 373 post-inoculation (pi).

In hematological examination, No. 3 had an acute increase in the count of $\operatorname{WBC}\left(85,600 / \mathrm{mm}^{3}\right)$ at day $1,203 \mathrm{pi}$. The counts of atypical mononuclear cells (AtMC) and mononuclear cells (MNC) were 77,896/. $\mathrm{mm}^{3}$ and 83,032/ $\mathrm{mm}^{3}$, respectively, and marked increases of large lymphoid neoplastic (NP) cells and mitosis were sporadically found on the blood smear. Then, from day 1,204 to day 1,211 pi, the counts of WBC, AtMC, and MNC were elevated in number from $89,800 / \mathrm{mm}^{3}$ to $176,000 / \mathrm{mm}^{3}$, from $78,126 / \mathrm{mm}^{3}$ to $172,480 / \mathrm{mm}^{3}$, and from $86,208 / \mathrm{mm}^{3}$ to $174,240 / \mathrm{mm}^{3}$, respectively. At day 1,214 pi, this sheep was euthanized by bleeding and necropsied. At this time, the count of AtMC was $194,880 / \mathrm{mm}^{3}$ and that of MNC was $201,276 / \mathrm{mm}^{3}$. In other animals, no significant hematological changes were found.
Gross lesion: Outcome, findings at necropsy, clinical and macroscopic total diagnosis and observation period are shown in Table 3. Lesions of lymphoma were found in Nos. 3 and 6 . There was no macroscopic lesion of lymphoma in any of the other 10 cases.

In No. 3, tumor tissue involved the abomasum wall (maximum thickness of $6 \mathrm{~cm}$ ), heart, cecum, urinary bladder, and adipose tissue around the colon. The tissue of systemic lymph nodes, including posterior mediastinal lymph nodes $(19 \times 4 \times 2 \mathrm{~cm}, 124 \mathrm{~g})$, intestinal and mesenteric lymph nodes, and hemolymph nodes (maximum size was same as the head of little finger, $1.5 \mathrm{~g}$ ) in almost the entire body became tumorous.

In No. 6 , tumor $(11 \times 10 \times 8 \mathrm{~cm}$ in size $)$ was found around the jejunum, which caused narrowing of this area with ulceration (maximum size was $4 \times 0.5 \mathrm{~cm}$, Fig. 1). From these findings, we determined the total diagnosis as lymphoma in the jejunum.

Histopathological and immunohistochemical examination: In No. 3, the NP cells infiltrated and proliferated in the lymph nodes, spleen, gastrointestinal tract from abomasum to cecum (Fig. 2), heart (mainly in the right auricle), and around the urinary bladder, liver, gall bladder and kidney. Because of marked infiltration and proliferation of NP cells, the normal architecture was lost or obscure in lymph nodes (from cortex to medulla), abomasum (from mucosa to muscularis), jejunumand ileum (from mucosa to serosa), whereas the spleen retained the structure of red and white pulp. From morphological characteristics, NP cells appeared to be devided into 3 types: Lymphobalstic, prolyphocytic, and lymphocytic NP cells (Fig. 3). Lymphoblastic NP cells were found mainly in cortex of lymph nodes, white pulp of spleen, from tunica propria mucosae to tunica submucosae in abomasum and cecum. Prolymphocytic and lymphocytic NP cell were found in other area including medulla of lymph nodes, or red pulp of spleen. Mitosis of 


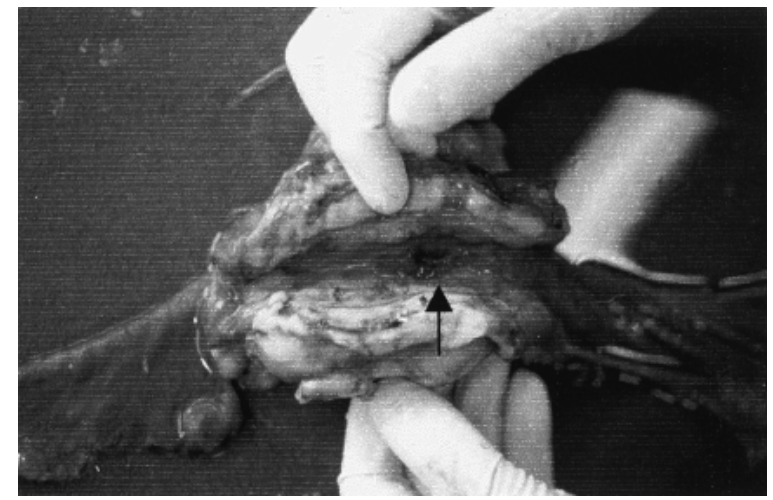

Fig. 1. Case No.6. Macroscopic findings of mass around jejunum and jejunum. Narrowing of jejunum and ulceration of mucosa (arrow) is seen.

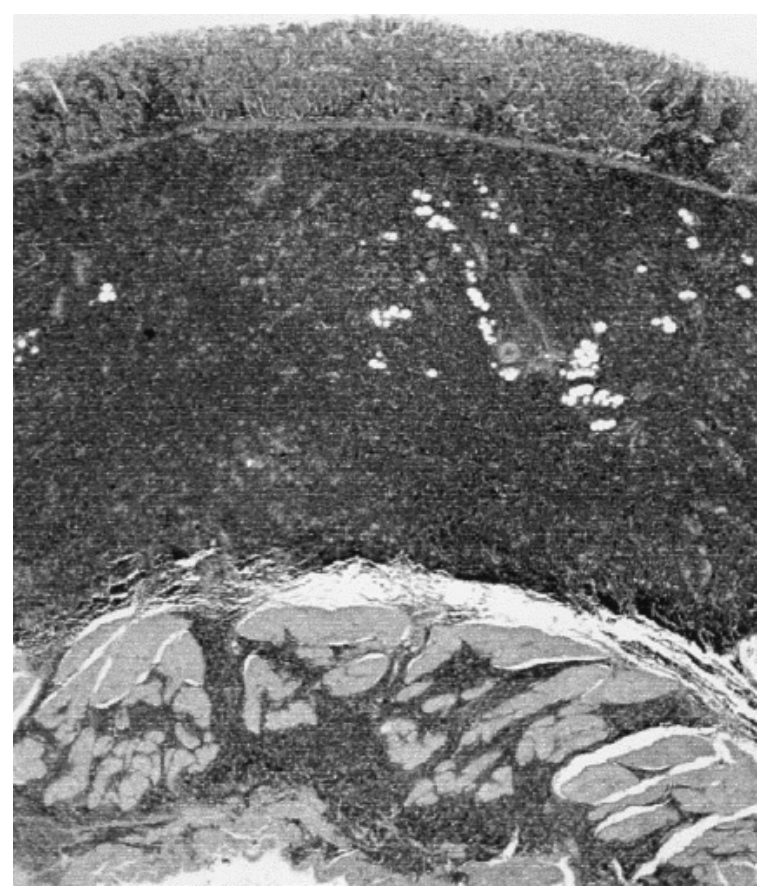

Fig. 2. Case No.3. Histopathological findings of cecum. Marked infiltration of NP cells from mucosa to lamina muscularis. HE stain, $\times 27$.

NP cells was also seen in some tissues. Additionally, in lymph nodes, interspersed histiocytes with phagocytosed lymphocytic debris produced the "starry sky" patterns. From these findings, the lymphoma in this sheep was thought to be diffuse mixed type [12].

In No. 6, the NP cells in the tumor mass around the jejunum exhibited 2 types of morphology: Lymphocytic, and prolymphocytic NP cells. These 2 types of cells mixed, infiltrated and proliferated diffusely. Additionally, mitosis of NP cells and starry sky patterns were sporadically seen, and necrotic foci were also found.

In the right auricle of the heart, small lymphocytic NP

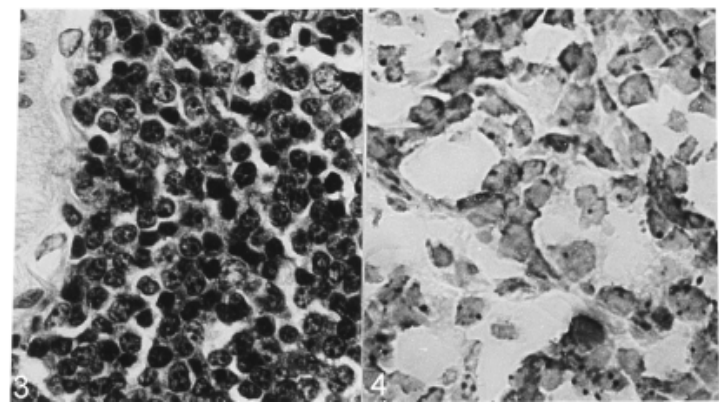

Fig. 3. Case No.3. The large magnification of Fig. 2. Morphologically, various type of NP cells are found. HE stain, $\times 500$.

Fig. 4. Case No. 6. Most NP cells in the mass around jejunum exhibit positive for B4. Dextran polymer immunocomplex method. BAQ155A, $\times 500$.

cells diffusely infiltrated and proliferated from the epicardium to adipose tissue, intermyocardium and endocardium.

From these findings, the lymphoma in this sheep was thought to be diffuse mixed type [12]. Lesions of lymphoma were locally found in the jejunum and heart, but not in the lymph nodes or spleen. The other 12 cases, which did not have macroscopic lesion of lymphoma, also did not have microscopic lesions.

On immunohistochemical examination, most NP cells of both No. 3 and No. 6 were positive for B-B4 (Fig. 4) and MHC class II, negative for CD5, CD8 $\alpha, \mathrm{CD} 1$ and CD4, and a few cells were positive for CD5. The percentage of antibody-positive NP cells for each antigen is listed in Table 2.

\section{DISCUSSION}

Although sheep do not exhibit the pathological status of PL [8], No. 3 had a MNC count over $20,000 / \mathrm{mm}^{3}$, and leukemic change in peripheral blood on hematological examination. The incidence of leukemia was $1 / 5$ in $\mathrm{H}$ group, and $0 / 6$ in $\mathrm{W}$ group. Comparing the 4 cases in $\mathrm{H}$ group (Nos. 1, $2,4,5$ ) except No. 3 that developed lymphocytic leukemia with 4 cases in W group (Nos. 6, 9-11) that had available data for change with time in count of WBC and MNC, there was no significant difference. On serological examination, incidence of pBLV-IF infection determined by ID examination was $5 / 5$ in $\mathrm{H}$ group, and $3 / 6$ in $\mathrm{W}$ group, so pBLV-IF infection was achieved with higher incidence in $\mathrm{H}$ group. Because tax protein activates expression and function of the BLV gene [16], it was thought that high tax induced more accelerated function of tax protein than did wild tax. However, we could not find the detailed mechanism.

We found NP cells in more organs of case No. 3, which exhibited leukemic status by histopathological examination than in No. 6, which did not exhibit leukemic status. In No. 3 , the proliferating NP cells were thought to be derived from more morphological immature lymphocytes than in No. 6, because lymphoblastic NP cells were found in lymph nodes, spleen and abomasum in No. 3 but not in No. 6. Addition- 
ally, lesions of lymphoma were locally found in the jejunum and heart, but not in the lymph nodes or spleen in No. 6 . This may be explained by that the proliferation of NP cells was inhibited by a host factor [11].

On immunohistochemical examination, the NP cells in No. 3 and No. 6 expressed sIgM, $\lambda$ light chain, MHC class II and B-B4, but not CD1, CD4, CD5 and CD8 $\alpha$. From these findings, the phenotype of NP cells in tumor tissue induced by pBLV-IF are thought to be $\mathrm{CD}^{-}, \mathrm{CD}^{-}, \mathrm{CD}^{-}, \mathrm{CD} 8 \alpha^{-}$, $\operatorname{sIgM}^{+}, \lambda$ light chain ${ }^{+}, \mathrm{B}-\mathrm{B} 4^{+}, \mathrm{MHC}$ class $\mathrm{II}^{+}$. This type is thought to belong to $\mathrm{CD}^{-} \mathrm{B}$ cell lineage.

Heeney and Valli [4] demonstrated that enzootic bovine lymphoma are tumors of mature B cells with common characteristics suggesting that pressures associated with BLV infection which favor tumor development are manifested late in B cell ontogeny, possibly during the isotype switch period. Aida et al. [1] reported that NP cells in EBL appeared to be divided into two types: $\operatorname{sIgM}^{+}$or $\operatorname{sIgM}^{-}$ mature B-cell lineages. Additionally, Murakami et al. [7] reported that neoplastic cells in sheep experimentally infected with BLV and developed lymphoma appeared to be classified as 2 immunogloblin isotypes: sIgM-expressing mature B cells, and expression of immunogloblin other than sIgM. Thus, the NP cells from our two sheep experimentally infected with pBLV-IF which developed lymphoma in this study may be classified into the $\operatorname{sIgM}^{+}$mature B cell lineage. Murakami et al. [7] classified the phenotypes of NP cells in tumorous lymph nodes induced by BLV into 2 types: $\mathrm{CD}^{-}, \mathrm{CD}^{-}, \mathrm{CD} 8 \alpha, \mathrm{sIgM}^{+}, \mathrm{B}-\mathrm{B} 2^{+}, \mathrm{MHC}$ class $\mathrm{II}^{+}$, and $\mathrm{CD}^{-}, \mathrm{CD}^{-}, \mathrm{CD} 8 \alpha^{-}, \mathrm{sIgM}^{-}, \mathrm{B}-\mathrm{B} 2^{+}, \mathrm{MHC}^{-}$class $\mathrm{II}^{+}$in sheep. In this study, the NP cells were thought to be classified as former type. Although some in vivo studies [3, 6, 13, 14] used recombinant BLV provirus to determine its infectivity, and successfully induced leukemia and lymphoma in sheep, to our knowledge, this is the first report of a pathological study of sheep induced with BLV high tax molecular clone.

ACKNOWLEDGEMENTS. We would like to thank students of the Department of Veterinary Pathology, Faculty of Agriculture, Iwate University for collecting samples. This study was supported by Grant-in-Aid for Scientific Research (B) No. 13460138 from Japan Society for the Promotion of Science.

\section{REFERENCES}

1. Aida, Y., Okada, K. and Amanuma, H. 1993. Phenotype and ontogeny of cells carrying tumor-associated antigen that is expressed on bovine leukemia virus-induced lymphosarcoma. Cancer Res. 53: 429-437.

2. Davis, W. C., Marusic, S., Lewin, H. A., Splitter, G. A., Perryman, L. E., McGuire, T. C. and Gorham, J. R. 1987. The development and analysis of species specific and cross reactive monoclonal antibodies to leukocyte differentiation antigens and antigens of the major histocompatibilitiy complex for use in the study of the immune system in cattle and other species.
Vet. Immunol. Immunopathol. 15: 337-376.

3. Gatot, J-S., Callebaut, I., Mornon, J-P., Portetelle, D., Burny, A., Kerkhofs, P., Kettmann, R. and Williems, L. 1998. Conservative mutations in the immunosuppressive region of the bovine leukemia virus transmembrane protein affect fusion but not infectivity in vivo. J. Biol. Chem. 273: 12870-12880.

4. Heeney, J. L. and Valli, V. E. O. 1990. Transformed phenotype of enzootic bovine lymphoma reflects differentiation-liked leukemogenesis. Lab. Invest. 62: 339-345.

5. Inabe, K., Ikuta, K. and Aida, Y. 1998. Transmission and propagation in cell culture of virus produced by cells transfected with an infectious molecular clone of bovine leukemia virus. Virology 245: 53-64.

6. Kerkhofs, P., Heremans, H., Burny, A., Kettmann, R. and Willems, L. 1998. In vitro and in vivo oncogenic potential of bovine leukemia virus G4 protein. J. Virol. 72: 2554-2559.

7. Murakami, K., Aida, Y., Kageyama, R., Numakunai, S., Ohshima, K., Okada, K. and Ikawa, Y. 1994. Immunopathologic study and characterization of the phenotype of transformed cells in sheep with bovine leukemia virus-induced lymphosarcoma. Am. J. Vet. Res. 55: 72-80.

8. Rogers, R. J., Chung, Y. S. and Dimmock, C. K. 1984. Development of lymphosarcoma in sheep after inoculation with bovine leucosis virus. Aust. Vet. J. 61: 196-197.

9. Sagata, N., Yasunaga, T., Tsuzuku-Kawamura, J., Ohishi, K., Ogawa, Y. and Ikawa, Y. 1985. Complete nucleotide sequence of the genome of bovine leukemia virus: Its evolutionary relationship to other retroviruses. Proc. Natl. Acad. Sci. U.S.A. 82: 677-681.

10. Tajima, S. and Aida, Y. 2000. The region between amino acids 245 and 265 of the bovine leukemia virus (BLV) tax protein restricts transactivation not only via the BLV enhancer but also via other retrovirus enhancers. J. Virol. 74: 10939-10949.

11. Tajima, S., Takahashi, M., Takeshima, S., Konnai, S., Yin, S., Watarai, S., Tana, Tanaka, Y., Onuma, M., Okada, K. and Aida, Y. 2003. A mutant form of the Tax protein of bovine leukemia virus (BLV), with enhanced transactivation activiy, increases expression and propagation of BLV in vitro but not in vivo. J. Virol. 77: 1894-1903.

12. Valli, V. E. O. and Parry, B. W. 1993. The hematopoietic systems. pp. 133-157. In: Pathology of Domestic Animals, vol. 3. 4th ed. (Jubb, K. V. F., Kennedy, P. C. and Palmer, N. eds). Academic Press, California.

13. Willems, L., Gatot, J, S., Mammerickx, M., Portetelle, D., Burny, A., Kerkhofs, P. and Kettmann, R. 1995. The YXXLsignalling motifs of the bovine leukemia virus transmembrane protein are required for in vivo infection and maintenance of high viral loads. J. Virol. 69: 4137-4141.

14. Willems, L., Kerkhofs, P., Attenelle, L., Burny, A., Portelle, D. and Kettmann, R. 1997. The major homology region of bovine leukaemia virus p2 $4^{\mathrm{gag}}$ is required for virus infectivity in vivo. J. Gen. Virol. 78: 637-640.

15. Willems, L., Portetelle, D., Kerkhofs, P., Chen, G., Burny, A., Mammerickx, M. and Kettmann, R. 1992. In vivo transfection of bovine leukemia provirus into sheep. Virology 189: 775777.

16. Yoshida, M. 2001. Multiple viral strategies of HTLV-1 for dysregulation of cell growth control. Annu. Rev. Immunol. 19: 475-496. 